Mirna Dumičić*

\section{Linkages Between Fiscal Policy and Financial (In)Stability ${ }^{1}$}

\begin{abstract}
This paper identifies and describes some of the main channels through which fiscal policy is linked to financial stability. For that purpose, several features of public debt related to financial stability are explored, such as public debt management and its sustainability, government's funding costs and their impact on costs of funding for private sector, financial institutions' exposures to the government etc. The part related to the tax policy elaborates on its countercyclical capacity, the role of automatic stabilizers, tax incentives that encourage or discourage certain type of financing, and impact of tax reliefs on systemic risks, particularly those targeted at the real estate. Fiscal policy role during the periods of strong capital inflows is also described from the financial stability point of view, which is followed by the overview of fiscal and quasi-fiscal costs of financial instability.Specific problem of different time horizon of economic policymakers', which is in the case of fiscal policy usually related to election cycles and thus negatively affects its countercyclical capacity, is also explored. Given the relevance of the identified channels for financial stability, it can be expected that macroprudential capacity of fiscal policy will gain much more attention in the future research and policy work.
\end{abstract}

Key words: fiscal policy, financial stability macroprudential policy, systemic risks

JEL: E60, E62, E58

1 The views expressed in this paper are those of the author and do not necessarily reflect the views of the European Central Bank or the Croatian National Bank.
${ }^{*}$ Croatian National Bank,

Zagreb, Croatia.

E-mail:

mdumicic@gmail.com 


\section{INTRODUCTION}

Fiscal policy has an immense macroprudential potential due to its numerous interlinkages with the financial system and real economy. Public debt management, tax policies, different structural and social measures, as well as other fiscal measures aimed at ensuring sustainable economic growth, higher employment and achieving social goals can both directly and indirectly affect systemic risk developments and capacity of the system to amortize potential shocks. Depending on its pro- or counter-cyclical character, fiscal policy could also significantly affect financial cycles.

Despite the unquestionable relevance of fiscal policy for preserving financial stability, literature dealing with this area is still relatively scarce. This is partially due to the fact that macroprudential framework is still evolving. However, this evolution has gradually started to change the perception of traditional fiscal policy objectives. Some of the recent academic debates suggest that financial stability should have the main role not only within the macroprudential policy, but also in conducting fiscal and monetary policy (Obstfeld, 2013), while some deliberations go even further by challenging the need for an independent macroprudential policy and implying that macroprudential principles should be incorporated into other economic policies - primarily fiscal and monetary policy (Clark and Large, 2011).

In order to contribute to this topic, this paper builds on work of Dumičić and Pečarić (2016) which presents a broad discussion about the importance of fiscal policy from the macroprudential perspective, and aims to identify and describe in more details some of the main links between different fiscal policy measures and instruments and financial stability. In addition to that, it also attempts to show the impact which episodes of financial instability could have in terms of fiscal and quasi-fiscal costs. For that purpose, in the second chapter several features of public debt related to financial stability are explored, such as public debt management and its sustainability, government's funding costs and their impact on costs of funding for private sector and pricing of riskier asset classes, financial institutions' exposures to the government etc. The part related to tax policy elaborates on its counter-cyclical capacity, role of automatic stabilizers, tax incentives that encourage or discourage certain type of financing (debt vs. equity) and impact of tax reliefs on systemic risks, particularly those related to the real estate taxation. Fiscal policy role during periods of strong capital inflows is also described from the financial stability point of view. This is followed by discussing the problem of different time horizons of economic policymakers which is, in the case of fiscal policy, usually related to the election cycles and thus negatively 
affects its countercyclical capacity. Third chapter brings an overview of potential fiscal and quasi-fiscal costs of financial instability (i.e. bailing out of financial institutions, protection of deponents and other creditors, different types of subsidies to the real economy or even households etc.), which additionally emphasize the relevance of macroprudential capacity of this, but also of other policies. The paper ends with main conclusions based on the explored linkages between fiscal policy and financial stability, implying that macroprudential potential of fiscal policy might be an inspiring area for future research.

\section{POTENTIAL CHANNELS OF IMPACT OF FISCAL POLICY ON FINANCIAL STABILITY}

Due to the relatively early stage of macroprudential policy development, a wide area of its application and effects is still unknown, especially concerning its interaction with other economic policies. In order to analyse the relations between instruments of different policies from the financial stability point of view, it is necessary to understand the ways in which other types of policies could affect it. Although financial stability is not a key goal of fiscal policy, some of its instruments have a significant influence on systemic risk developments and the system's capacity to absorb shocks. If macroprudential and fiscal policy are well coordinated, this significantly reduces the likelihood of crisis episodes (Dumičić, 2017). On the other hand, if fiscal policymakers do not take into account financial stability aspects of their actions, it can also have severe negative implications for the financial system and the society as a whole.

Therefore, fiscal policy measures seem to be very useful tools for macroprudential purposes. In their overview of fiscal policy objectives which affect financial stability and the accompanying tools and instruments, Bikas and Žaltauskaite (2014) emphasize three main areas in which fiscal policy could influence financial stability - public demand, fiscal buffers and the ability of fiscal policy to provide help to financial sector in crisis situations. Similar approach is also used in this chapter, which describes the most important ways in which fiscal policy measures and activities could affect systemic risks and the resilience of financial system. Main focus is put on public debt, funding costs for government and private sector, tax strategies, automatic stabilizers, impact of fiscal policy on aggregate demand, relation between fiscal policy and volatile capital flows and time horizon of different economic policies. 


\subsection{Public debt and budget deficit}

Financial stability depends heavily on government's financial position or, more precisely, on market participants' perception of its prudency. A wise fiscal policy that ensures long-term sustainability of public debt minimizes the need for classical macroprudential measures by simultaneously reducing systemic risks and increasing the resilience of economy to potential shocks. Komárková, Dingová and Komárek (2012) argue that such behaviour is compatible to creating capital and liquidity buffers on the system level, which puts sustainable fiscal policy next to monetary and macroprudential policy in terms of their importance for the overall financial stability.

Literature shows that public debt sustainability depends on various factors, such as: nominal value, relative value compared to the size of economy, term and currency structure of debt, origin of creditors (domestic vs. foreign), type of creditors, monetary policy of most important central banks, current domestic and international market and economic conditions, budget structure, political stability, quality of domestic financial institutions, geopolitical developments etc. Despite many attempts of defining a universal threshold level of the sustainable share of public debt in GDP, the practice has disproved these attempts. Nevertheless, there is no doubt that higher level of public debt reduces the countercyclical capacity of fiscal policy and puts additional pressure on other economic policies, which becomes crucial in crisis situations when government's financial interventions are needed for mitigating consequences of such episodes (Clark and Large, 2011). Therefore, the public debt to GDP ratio is used as one of the variables for assessing systemic risks associated with the government (Dumičić, 2015).

The structure of the debtors in terms of their origin plays a role when determining the impact of potential problems with servicing public debt on overall financial stability. In that sense, domestic funding sources are usually perceived as more stable. However, if the exposures of domestic sectors to the government are not adequately regulated, they could amplify systemic risks, especially in small open economies where these exposures might be concentrated in relatively small number of entities. This refers not only to the financial sector, but also to non-financial corporations which also often invest in government bonds. On the other hand, foreign funding sources are much more diversified, but they are also more volatile and subjective to sudden reversals. Capital flows depend on various factors, such as global liquidity, global interest rates or risk perception of certain region, while domestic macroeconomic conditions, which could partly be influenced by government and domestic players, do not necessarily have a very important role in their determination. In addition, foreign creditors usually prefer debt 
issued in foreign currency which increases the level of currency risk in domestic economy. This risk can be avoided, but only at additional costs. Highly euroized countries have a particularly limited manoeuvring space in tackling this type of risk as government receives income in domestic currency, while the major part of liabilities is denominated in foreign currency. In such situation, even a milder fluctuation of exchange rate of domestic currency versus the currency of debt denomination could switch the sustainable debt position into the unsustainable one and result in a sovereign default.

Risks related to government finances are also contained in the balance sheets of a major part of domestic economic system and potential debt servicing problems of the government would inevitably spread around the whole financial system in a very short time. Another aspect of this risk, as emphasized by Praet (2011), is related to the role of sovereign securities as collateral in refinancing operations. Apart from their dispersion within the domestic economy, risks related to government's debt servicing ability could also lead to cross-border spill-overs of these risks to countries with financial or trade linkages with the country in trouble (Obstfeld, 2013).

The described awareness of systemic relevance of financial institutions' exposures to the government debt combined with concerns about its sustainability has initiated discussions on the justification of prevailing practice according to which government debt has been treated as a "non-risky" asset. This approach has generally been justified by the fact that governments can issue their own currency and repay the debt, resulting with the associated risk weights of zero per cent. As noted by the Bank for International Settlements (2016), there are three potential arguments against this view - institutional constrains might in certain occasions disable debt monetisation; subnational entities and government owned companies can still default; and even if the government does not default, high volatility of price of its bonds and country risk premium could result in a strong deterioration of financing conditions for other sectors. As a consequence of these deliberations, the regulatory treatment of sovereign exposures has been re-examined in order to protect financial system from potential losses in case of sovereign default. Report prepared by the European Systemic Risk Board (ESRB, 2015) explicitly warns of weaknesses of current regulatory framework which encourages high exposures of financial institutions to governments and discusses several areas of banking sector regulation which could be enhanced in this context, such as Pillar 1 and Pillar 2 requirements, coverage of sovereign exposures in macro-prudential regulation, better regulation of liquidity risk and stricter disclosure requirements on banks' sovereign exposures. It also explores regula- 
tory options of government debt treatment for other sectors, such as insurance companies.

\subsection{Funding costs for domestic economy}

The country risk determines funding costs for government, but also for the private sector. It is very rare that a company based in a certain country pays lower interest rates than the government. Rare exemptions from this rule are blue-chip companies which sometimes have higher credit rating than a country of their origin. Level of country risk, which is then transposed into the price of borrowing, is usually calculated against a certain benchmark rate. For example, in case of European countries, investors usually calculate the difference between government bond yields of comparable maturities for a specific country and Germany.

There is a broad literature exploring the determinants of country risk premium which are usually divided in the global market sentiment and expected macroeconomic and financial developments in a specific country. In other words, this means that domestic economic policies can only partially influence the level of these costs. Nevertheless, in their analysis focusing on the importance of fiscal policy in determining the risk premium, Bobetko et al. (2011) show that investors pay a special attention to the current, and particularly to the expected, values of fiscal indicators such as public debt or fiscal balance and confirm that negative expectations related to these variables directly increase funding costs for domestic economy. In addition, due to their specific characteristics - low risk and high liquidity, government securities also serve as a benchmark rate for assessing the prices of other assets classes (Das et al., 2010). This implies that private sector funding costs largely depend on the government's fiscal performance and that their deterioration could limit their access to funding sources, which would eventually spread throughout the whole financial and economic system and result in financial instability.

\subsection{Tax policies}

In general, consistent and stable tax policy framework is an essential component of fiscal policy which aims to contribute to overall stability of the financial system. Clear tax strategy and rules that are not subject to sudden changes contribute to economic growth, lower risks perception, and increase of the overall credibility of fiscal policy. 
Cyclical instruments are an important part of every stabilization policy and, from the fiscal policy domain, automatic stabilizers such as corporate and personal taxes are the most efficient ones. Channels through which tax policies could have a strong pro- or counter-cyclical impact on domestic economy are numerous. One of the examples of such measure is tax treatment of different types of financing. Brezenau and Vlad (2015) draw attention to the potential "debt bias" which indicates an increased preference of corporate sector for debt financing induced by more favourable tax treatment compared to equity funding. Another relevant issue is related to discussions on bank capital requirements and refers to tax deductibility of interest expenses on debt, which is, according to Schepens (2016), often neglected. He emphasizes that a more balanced approach in taxing these two types of financing could have a positive impact on financial stability as it would encourage banks to use less leverage.

Timing of introduction or abolition of certain tax measures also matters in the context of financial stability. Introduction of new taxes on specific asset classes during the upswings, especially if their prices are growing without support in fundamentals, reduces the probability of price bubbles and negative consequences of their bursting and vice versa.

Housing taxation policy is another powerful tool with strong potential macroprudential effects stemming from its impact on investment and consumption decisions. Tax treatment of housing purchases directly affects real estate prices and demand for such type of investment and it is also considered to be one of the most common sources of fiscal policy procyclicality. If tax reliefs for interest rates on housing loans are applied in the boom stage of the cycle, this additionally increases demand and pushes prices up, contributing to the creation of a bubble and magnifying the negative consequences when the trend reverses. Based on the OECD Housing market questionnaire, Andrews et al. (2011) calculate an indicator which, in line with the Johanson's methodology (2011), takes into account several factors: a) whether interest payments on mortgage debt can be deducted from the taxable income, $b$ ) the existence of limits related to the allowed deduction period or the amount that could be deducted; and c) whthere there are tax credits for loans. Relatively big differences between values of that indicator show that these policies significantly differ among countries. When discussing risks related to the real estate taxation, Lindén and Gayer (2012) also stress out the need to ensure that registers of real estate prices for tax purposes appropriately reflect current market conditions. If most recent developments were neglected, this could increase price imbalances between different regions and also cause a significant drop of future tax revenue due to inflation. 


\subsection{Capital flows}

Most of the countries have experienced at least one period of strong capital inflows. Depending on the size of a country, its level of development and main driving forces behind these capital inflows, such episodes could affect countries in different ways, requiring various policy actions. Although it is clear that both monetary and macroprudential policy could be efficient in addressing some of the risks accompanying the prolonged periods of strong capital inflows, Ghosh et al. (2017) explicitly emphasize that the most efficient instrument for this purpose is tighter, countercyclical, fiscal policy. This might refer to tax policies aimed at discouraging investments in certain assets or sectors, such as those to the nontradable sector, or certain types of financing, i.e. debt financing; or running a budget surplus and increasing the resilience of the system.

In spite of that, Reinhart and Reinhart (2008) note that fiscal policy stance in such cases is usually procyclical as government expenditures increase, and that it acts in a destabilizing manner assuming that these flows will be continuous, especially in developing markets. This has also been confirmed by the recent analysis of 50 emerging market countries conducted by Ghosh et al. (2017) which shows that fiscal policy is the least used tool for mitigating these risks and that countries prefer to use monetary and macroprudential policies, or even capital controls.

\subsection{Time horizon of fiscal policy and financial stability}

Within the countercyclical approach inherent to the macroprudential concept, policies should adjust to financial and economic cycles and build up protection mechanisms in the boom stages of the cycles, which can then be used in the bust stage to moderate the downturn and mitigate negative consequences of crisis episodes.

Although it sounds reasonable, this is relatively difficult to achieve in real life because fiscal policy usually faces an objective constrain - the election cycles. This fact by definition discourages activities which produce results observable only in the long run and indirectly encourages its procyclicality, i.e. if the potentially unsustainable public debt level limits the space for fiscal stimulus of growth during the recession, this period should be used for introducing reforms aimed at ensuring sustainable economic growth in the future. Unfortunately, reforms cannot be done in a short term, which reduces their attractiveness from the politicians' point of view. 
In that respect, the responsibility of voters should also be mentioned as they in essence prefer pro-cyclical behaviour when economy is growing. According to Alesina and Tabellini (2005), broad public would usually be against raising buffers during boom periods, i.e. by increasing taxes, as their basic attitude is always to demand more public goods or lower taxes, which they compare to the strategy of "starving the Leviathan".

\section{FISCAL COSTS AND FINANCIAL INSTABILITY}

Potentially enormous fiscal and quasi-fiscal costs of crisis episodes are the main argument for designating preservation of financial stability as one of the primary goals of the society. At the same time, they are also the main reason why fiscal policy is more and more interested in this issue independently of the actual causes of such episodes which might not necessarily be associated with it.

Numerous studies have attempted to estimate fiscal costs of financial instability. Their results depend on various factors, such as the size of economy, its openness, stage of development, currency regime, levels and structure of debt, etc. Data presented by Laeven and Valencia (2012) based on 19 crises episodes show that in extreme scenarios like the Argentinian (1980 - 1982) or the Indonesian (1997 - 2001) these costs could exceed 55\% of GDP, while on the total sample of the countries they varied between $2 \%$ and $57 \%$ of GDP.

Direct fiscal costs usually refer to the resolution of financial institutions such as bank recapitalizations, but they also include asset purchases, depositor payouts or calls on guarantees (Amaglobeli et al., 2015). As clarified by Janáček et al. (2012), fiscal help to the financial system in the form of recapitalizations and state guarantees directly harms public debt indicators and negatively affects the interest rate paid for this debt. Indirect fiscal costs are the consequence of adverse macroeconomic developments and include increased borrowing costs, discretionary fiscal stimulus and automatic stabilizers (Amaglobeli et al., 2015), but they also materialize in a form of prolonged recessions, output loss, less productive use and allocation of resources and a strong increase of public debt (Dumičić and Pečarić, 2016).

Countercyclical aspect of fiscal policy also matters in terms of costs of potential instability. Analysis of policy reaction in 140 banking crises in advanced and emerging markets between 1980 and 2012 conducted by Baldacci et al. (2012) confirms that countercyclical fiscal policy lowers costs and duration of episodes of financial instability as it stimulates aggregate demand. As explained by Mus- 
grave and Musgrave (1989), fiscal stabilization capacity is primarily reflected on its effect on the aggregated demand through public expenditures. However, Alesina and Tabellini (2005) show that in practice, government spending and public deficits measured as a share of GDP usually increase in upswings and go down in recessions. This suggests that fiscal capacity to support the falling economy is reduced or even non-existent if there are no buffers against potential shocks. Sufficient fiscal space which would allow expansionary fiscal policy is therefore a prerequisite for efficient reactions in crisis situation (Baldacci et al, 2012).

Potential pressure on the budget and government's ability to help the financial sector also depend on relation of revenues to the size of the financial sector (Komarkova and Komarek, 2015). In some countries, huge bulk of systemic risks is a consequence of the disproportional size of the financial system compared to the rest of the economy. The capacity of fiscal but also of other economic policies to serve as the shock amortises in such cases is significantly lower. Amaglobeli et al. (2015) confirm that the main amplifiers of direct and overall fiscal costs of banking crises include large banking sectors, especially if they primarily lean on foreign funding, but they also point that prudent banking supervision combined with adequate deposit insurance coverage could help lowering direct fiscal costs of crisis situations. In that sense, Deposit Guarantee Schemes (DGS) are directly aimed at reducing risks for the budget and they enable more efficient crisis management. As defined by the European Commission, the DGS protects depositors if a bank fails and uses funds collected from banks to cover up for their deposits up to a certain predefined level, meaning that there is no need to use taxpayers' money.

Moreover, fiscal costs of crisis episodes also largely depend on the efficiency of crisis management on the national and international level, particularly when government has to rescue financial institutions. This additionally emphasizes the necessity of legally defining a clear framework for cooperation of all actors that could affect financial stability in order to ensure the exchange of information which would enable timely reaction when crisis emerges. These inputs should guide the decisions on fiscal support to certain subjects or sectors and should minimize the size of such interventions.

\section{CONCLUSION}

Even though macroprudential capacity of fiscal policy is evident, the areas of transmission channels and its interaction with other economic policies in that context are still insufficiently explored. Majority of fiscal policy measures and 
activities, such as public debt management, tax policies and other structural and fiscal measures aimed at creating preconditions for a sustainable economic growth and achieving social goals, have direct or indirect influence on systemic risks and capacity of the system to absorb shocks. Furthermore, fiscal policy impact on financial cycles directly affects the level of buffers that could amortize negative consequences of financial crisis.

This paper points to potential ways in which fiscal policy could affect financial stability and attempts to raise awareness about its ability to lower the probability of materialization of systemic risks and to increase resilience of the financial system and overall economy to potential shocks. By accentuating the importance of its countercyclical approach, it also encourages countries to wisely use periods of favourable macroeconomic and financial conditions, which would imply lowering debt and strengthening the countercyclical potential of fiscal stabilizers.

Given the relevance of the identified channels of influence of fiscal policy on financial stability, it can be expected that macroprudential potential of fiscal policy will gain much more attention in the future research and policy work.

\section{Acknowledgement}

This work has been partially supported by the Croatian Science Foundation under the project "Public Finance Sustainability on the Path to the Monetary Union - PuFiSuMU” (IP-2016-06-4609). 


\section{REFERENCES}

1. Alesina, A., \& Tabellini, G. (2005). Why is Fiscal Policy Often Procyclical, NBER Working Paper Series 11600, July.

2. Amaglobeli, D., End, N., Jarmuzek, M., \& Palomba, G. (2015). From Systemic Banking Crises to Fiscal Costs: Risk Factors, IMF Working Paper WP/15/166, July.

3. Andrews, D., Caldera Sánchez, A., \& Johansson, Å. (2011). Housing Markets and Structural Policies in OECD Countries, OECD Economics Department Working Papers, No. 836, OECD Publishing.

4. Baldacci, E., Gupta, S., \& Mulas-Granados, C. (2012). How Effective is Fiscal Policy Response in Financial Crises?. Fiscal issues and central banking in emerging economies, BIS Papers (20) (2012), pp. 1-9.

5. Bank for International Settlements (2016). Towards a financial stabilityoriented fiscal policy. 86th Annual Report, 2015/16.

6. Bikas, E., \& Žaltauskaite, S. (2014). The Role Of Fiscal Policy in Ensuring Financial Stability in Lithuania. 8th International Scientific Conference "Business and Management 2014". 199-206. May 15-16, 2014, Vilnius, Lithuania.

7. Bobetko, A., Dumičić, M., \& Funda, J. (2013). Fiscal Determinants of Government Borrowing Costs - Do we have ourselves to blame?, Financial Theory and Practice, Vol. 37 (1), 135-159.

8. Brezeanu, P., \& Vlad, C. (2015). Macroprudential Tools and Their Interference with fiscal policy, International Conference of the Institute for Business Administration in Bucharest, 2015.

9. Clark, A., \& Large, A. (2011). Macroprudential Policy: Addressing the Things We Don't Know, Group of Thirty, Occasional Paper No. 83, Washington, DC.

10. Das U. S., Papapioannou, M., Pedras, G., Ahmed, F., \& Surti, J. (2010). Managing Public Debt and Its Financial Stability Implications, IMF Working Paper WP/10/280, December.

11. Dumičić, M., 2015, Financial Stability Indicators - The Case of Croatia, Journal of Central Banking Theory and Practice, Vol. 5, No. 1, 115-142, January.

12. Dumičić, M. \& Pečarić, M., 2016, Značaj makroprudencijalne politike u sklopu ekonomske politike, Ekonomija/Economics 22 (2), 265-280.

13. Dumičić, M., 2017, A Brief Introduction to the World of Macroprudential Policy, Journal of Central Banking Theory and Practice, Vol. 6, No. 1, 87109, January. 
14. Lindén, A.J., \& Gayer, C. (2012). European Economy - Possible reforms of real estate taxation: Criteria for successful policies. European Commission, Directorate-General for Economic and Financial Affairs. Occasional Papers 119 , October.

15. European Systemic Risk Board (2015). ESRB report on the regulatory treatment of sovereign exposures. March.

16. Ghosh, A.R., Ostry, J.D. \& Quereshi, M.S. (2017). Managing the Tide: How Do Emerging Markets Respond to Capital Flows?, IMF Working Paper WP/17/69, March.

17. Janáček, K., Hlaváček, M., Komárek, L., \& Komárková, Z. (2012). Impacts of the Sovereign Default Crisis on the Czech Financial Sector, CNB, Financial Stability Report 2011/2012

18. Johansson, A. (2011). Housing Policies in the OECD and Candidate for Accession Countries: Survey based Data and Implications, OECD Economics Department Working Papers.

19. Komárek, L. \& Komárková, Z. 2015, Financial Stability and the Sovereign Default, Proceedings of the International Conference on Global Business, Economics, Finance and Social Sciences (GB15_Thai Conference), Bangkok, Thailand, 20-22 February.

20. Komárková, Z., Dingová, V. \& Komárek, L. (2012). Fiscal Sustainability and Financial Stability, Czech National Bank, Financial Stability Report 2012/2013.

21. Musgrave, R.A. \& Musgrave, P.B. (1989). Public Finance in Theory and Practice. McGraw-Hill Book Company. United States of America.

22. Obstfeld, M. (2013). On Keeping Your Powder Dry: Fiscal Foundations of Financial and Price Stability, University of California, Berkley, Cepr and NBER, June.

23. Praet, P. (2011). Economic, Financial and Monetary Stability in Europe: Reinforcing Our Policy Instruments, Bank for International Settlements. BIS Papers No. 59, December.

24. Reinhart, C., \&. Reinhart (2008). Capital Flow Bonanzas: An Encompassing View of the Past and Present, NBER Working Paper No. 14321, September.

25. Schepens, G. (2016). Does the tax advantage of debt impact financial stability?. European Central Bank, Research Bulletin No. 27. September. 